$\begin{array}{r}\text { Contents lists available at BIOSFER } \\ \text { BIOSFER: JURNAL TADRIS BIOLOGI } \\ \text { p-ISSN: 2086-5945 (print), e-ISSN: 2580-4960 (online), DoI 10.24042/biosfer } \\ \text { http://ejournal.radenintan.ac.id/index.php/biosfer/index } \\ \hline \hline\end{array}$

\title{
Isolation, Characterization and Activity Test of Soil Origin Bacteria Amilage
}

\author{
Monica Kharisma Swandi ${ }^{*}$ \\ ${ }^{1}$ Bangka Belitung University, Indonesia
}

\section{ARTICLE INFO}

\section{Article History}

Received: 07-07-2020

Accepted: 03-03-2020

Published: 31-12-2020

Keywords:

Amylase Activity;

Isolation and Characterization;

Soil Bacteria.

*Correspondence Address: monica_swandi@apps.ipb.ac.id

\begin{abstract}
This study aimed to obtain amylase-producing potent bacteria from soil and test the amylase activity produced. Soil samples were taken from the Biological Education and Research Forest, Andalas University. The isolation was done by using the stratified dilution technique on agar media. The screening of amylase activity employed the qualitative and quantitative tests on agar starch. From 8 isolated amylolytic bacteria, there were three isolates with amylolytic potential. The results of characterization and identification based on Bergey's Manual of Determinative Bacteriology show that isolates A4, A1, and A6 belonged to the genus Bacillus, Corynebacterium, and Klebsiella. The bacteria obtained can then be produced and optimized for the needs of industrial enzymes.
\end{abstract}

\section{Isolasi, Karakterisasi dan Uji Aktivitas Amilase Bakteri Asal Tanah}

\begin{abstract}
Abstrak: Penelitian ini bertujuan untuk memperoleh bakteri potensif penghasil amilase asal tanah dan menguji aktivitas amilase yang dihasilkan. Sampel tanah diambil dari Hutan Pendidikan dan Penelitian Biologi, Universitas Andalas. Isolasi dilakukan dengan teknik pengenceran bertingkat pada media agar. Penapisan aktivitas amilase menggunakan uji kualitatif dan kuantitatif pada media agar pati. Dari 8 bakteri amilolitik yang diisolasi, didapatkan 3 isolat yang berpotensi amilolitik. Hasil karakterisasi dan identifikasi berdasarkan Bergey's Manual of Determinative Bacteriology menunjukkan bahwa isolat A4, A1, dan A6 termasuk dalam genus Bacillus, Corynebacterium, and Klebsiella. Bakteri yang didapatkan selanjutnya dapat diproduksi dan dioptimasi untuk kebutuhan enzim industri.
\end{abstract}

\section{INTRODUCTION}

Enzymes are proteins that serve as catalysts in a chemical reaction in the body of living things (Arifin, 2008; Febriani \& Rahmadina, 2017). Enzymes are specific to the substrate (Pratiwi et al., 2014; Wardani 
et al., 2014) and can produce main products with almost no byproducts (Burhanudin et al., 2020; Putra et al., 2014; Rusli, 2016). Enzymes also have hydrolytic properties that break down complex molecules into simple molecules (Anggraini \& Yunianta, 2014; Osvaldo et al., 2012; Rokhati et al., Nd). These properties make enzymes widely used for various industrial processes. One of them is the amylase enzyme(Ningsih et al., 2010; Supriyatna et al., 2015). An amylase is a group of enzymes that can break the glycoside bonds found in starch polymers (Rakhmawati et al., 2012; Sukandar et al., 2018). Amylase consists of $\alpha$-amylase, $\beta$-amylase, and $\gamma$ amylase, a group of enzymes that utilize starch as a source of carbon and energy (Nangin \& Sutrisno, 2014; Vaidya et al., 2015). Starch is hydrolyzed by amylase into simple sugars such as maltose, dextrins, and glucose (Silaban \& Simamora, 2018; Siregar, 2014).

The demands for amylase enzymes in the industrial sector increased every year. Bacteria that can produce amylase enzymes are used to meet the demand (Ningsih et al., 2010; Susilawati et al., 2015). Amylase enzymes can be found in starch processing industries, such as food, textile, pharmaceuticals, cosmetics, fermentation, and paper industries (Vishnu et al., 2014). The demands for amylase for the industrial sector increased every year (Kartawijaya, 2014). Thus, a solution is needed to meet these needs by using bacteria that produce amylase (Ardiansyah et al., 2018; Kalesar et al., 2013). Nangin and Sutrisno (Nangin \& Sutrisno, 2014) reported several amylase-producing bacteria, namely Bacillus amyloliquifaciens ABBD, Bacillus aquamaris MKSC 6.2, Bacillus subtilis 65, Bacillus licheniformis ATCC 9945a, Geobacillus thermodenitrificans, and Klebsiella pneumoniae.

Bacterial-based amylase is easier and more beneficial than other living beings (Haryati \& Munandar, 2016). It is because bacteria are easy to cultivate, grow fast, and can produce large and varied amounts of enzymes. Besides, bacteria can withstand physical and chemical environmental factors (Abel-Nabey \& Farag, 2016). A study was conducted to obtain potential isolates for amylase-producing sources from the soil to fulfill the industrial need for enzymes (Purnawan et al., 2016; Remijawa et al., 2020). Previous research studied amylase activation (Susilawati et al., 2015), amylase from shrimp paste (Oktavia et al., 2018), and amylase from water sources (Fifendy et al., 2015). However, research on the isolation of amylase from soil has not been studied before. This research is expected to utilize the amylase enzyme from local bacteria to develop industrial enzyme production. Therefore, this research aimed to obtain amylase-producing potent bacteria from the soil and test the resulting amylase activity.

\section{METHOD}

This research is a laboratory experimental study that provides an overview of the object under study, namely amylase enzyme-producing bacteria originating from the soil in the Biological Education and Research Forest (HPPB) area, Andalas University, Padang. The research stages consisted of isolating and purifying bacteria, selecting bacteria based on their ability to produce amylase enzymes using qualitative and quantitative tests, characterizing bacteria based on the morphology and physiology, and identifying bacteria using Bergey's Manual of Determinative Bacteriology.

The materials used in this study were soil taken from HPPB Andalas University, nutrient agar media containing $1 \%$ starch (NA 1\% starch), nutrient broth containing $1 \%$ starch (NB 1\% starch), crystal violet, aquades, iodine, alcohol, safranin, green malachite, DNS reagent, Bradford reagent, Bovine Serum Albumin (BSA) solution, and media for physiological testing. The tools used in this study were the UV-Vis spectrophotometer, magnetic stirrer, centrifuge, incubator, vortex, autoclave, 
microscope, loop needle, analytical scale, dropper pipette, spreader rod, bunsen, and general glass tools used in laboratories. Ten grams of soil were dissolved in $90 \mathrm{~mL}$ of $1 \%$ NB starch and then incubated in a shaking incubator for 24 hours at room temperature. The isolation was carried out by serial dilution method $10-1$ to $10-5$ in $0.85 \% \mathrm{NaCl}$ solution. The dilution of $0.1 \mathrm{~mL}$ was inoculated into 1\% NA medium starch using the spread plate and then incubated for 48-72 hours at room temperature. Bacteria growing on the medium were observed, and several different colonies were selected for purification. The purification was carried out by quadrant scratching method on NA medium 1\% starch and incubated for 48 hours at room temperature. The single colonies formed were grown on slant culture with the same medium as the stock and stored for further testing.

The pure bacterial colonies were taken using a loop needle, then dotted on NA $1 \%$ starch medium and incubated for 24 hours at room temperature. The growing bacterial colony was then dripped with iodine solution so that the clear zone formed around the colony could be clearly visible. Pure isolates were taken using ose then inoculated in $100 \mathrm{~mL}$ of $1 \%$ NB starch medium. Then, the inoculum was shaken at
$100 \mathrm{rpm}$ for 48 hours at room temperature. The inoculum was transferred to a $1.5 \mathrm{ml}$ microtube and centrifuged at $10000 \mathrm{rpm}$ for 10 minutes. The supernatant resulting from centrifugation contains crude enzyme extract used to test amylase enzyme activity and protein content. Physiological characters were observed based on the catalase test results, indole test, and carbohydrate fermentation test (glucose, sucrose, lactose, dextrose).

\section{RESULTS AND DISCUSSION}

There were eight isolates obtained as the results of bacterial isolation based on different morphological characters. The colonies that grew were assumed as amylolytic bacteria because they could grow on NA media containing 1\% starch, indicating that the bacteria can use starch as a nutrition source. Starch is one of the soil organic materials that determine the soil microbial community. Therefore, to determine the bacteria that can degrade starch, a further test was carried out, namely the qualitative test of amylolytic bacteria. The test results are expressed in the degradative index value presented in Table 1.

Table 1. Hydrolysis Index Value of Amyl Bacteria Starch olitik

\begin{tabular}{cccc}
\hline Isolate Code & $\begin{array}{c}\text { Average Diameter of } \\
\text { Clear Zone } \mathbf{( c m )}\end{array}$ & $\begin{array}{c}\text { Average Diameter of } \\
\text { Colony Area } \mathbf{( c m )}\end{array}$ & Index Value \\
\hline A1 & 1,2 & 0.5 & 1.4 \\
A2 & 0.8 & 0.6 & 0.3 \\
A3 & 2.5 & 1.4 & 0.8 \\
A4 & 2,2 & 0.6 & 2.7 \\
A5 & 1,1 & 0.7 & 0.6 \\
A6 & 1.9 & 0.7 & 1.7 \\
A7 & 2,4 & 2,2 & 0.1 \\
A8 & 0.6 & 0.5 & 0.2 \\
\hline
\end{tabular}

Table 1 shows the degradative index values for eight different isolates. The results indicated that bacteria's ability to hydrolyze starch varied, depending on the 
diffusion ability of the extracellular amylase enzyme produced by each bacteria. The hydrolysis ability is seen from how big the colony forms a clear zone. Of the eight isolates, three isolates were selected with the highest index value, namely isolates A4, $\mathrm{A} 6$, and $\mathrm{A} 1$, with index values of $2.7 ; 1.7$; and 1.4. They were further tested in a quantitative amylase enzyme test.

In this test, the iodine solution was used as an indicator to test the presence or absence of starch content after dropping it on the media. If the media contains starch, there will be a complex reaction between the starch and iodine solution, causing the media to change color to purple or blackish blue. Bacteria with amylase extracellular enzyme activity can hydrolyze the starch in the medium so that the degraded starch cannot bind to the iodine and produce a clear zone around the bacterial colony. The larger the clear zone formed, the greater the ability of bacteria to produce extracellular amylase enzymes to hydrolyze the starch. According to Singh (Singh et al., 2015), starch is hydrolyzed by bacteria into small monomers, namely maltose or glucose. These monomers are formed due to the $\alpha$ 1,4 glycoside bonds breaking in the polysaccharide chain by the amylase enzyme.

The high activity is seen based on the high index value based on large clear zones and small bacterial colonies. The largest clear zone was produced by isolate A3, which was $2.5 \mathrm{~cm}$ with a large bacterial colony diameter $(1.4 \mathrm{~cm})$. Therefore, the calculation of the index value was small, namely 0.8. The A4 isolate had a smaller clear zone, but the bacterial colony was not that big. The calculation of the index value would also be higher, which was 2.7. A smaller clear zone does not mean it has small activity because it is determined by the penetration ability, the number of molecules, and the molecules' size. Another affecting factor is the environment, such as temperature, incubation time, and the media's consistency.

The results of amylase enzyme activity were obtained from the calculation of reducing sugar levels based on the regression equation formed from the standard glucose curve. Table 2 shows that isolate $\mathrm{A} 4$ has the highest enzyme activity, namely $2.07 \mathrm{U} / \mathrm{ml}$, which means that in $1 \mathrm{ml}$ of crude extract enzyme, the amylase enzyme activity would be $2.07 \mathrm{U} / \mathrm{ml}$, which can hydrolyze starch to $1 \mu \mathrm{mol}$ of glucose for 1 minute.

The reducing sugar test is closely related to the measurement of enzyme activity. Reducing sugars are a group of sugars (carbohydrates) that can reduce electron-accepting compounds such as glucose. The higher the enzyme activity, the higher the reducing sugar produced will be (Melliawati \& Nuryati, 2019). The reducing sugar will be bound by DNS, which produces an orange color. The color density can indicate how much reducing sugar is produced. The highest reducing sugar content was obtained from isolate A4. According to Nangin and Sutrisno (Nangin \& Sutrisno, 2014), big or small levels of reducing sugar obtained can be affected by the level of enzyme purity. The enzyme used a crude extract enzyme that contained other components or other proteins that served as inhibitors that can interfere with the enzyme work (Melliawati \& Nuryati, 2019). Other factors that can affect enzyme activity are incubation temperature, incubation time, type of medium, type of starch substrate, and the amount of starch substrate used in enzyme production. 
Biosfer, 10 (1) (2020) 181-189

Monica Kharisma Swandi

Table 2. The Results of Protein Levels and Amylase Enzyme Activity Measurements

\begin{tabular}{ccccc}
\hline Isolate Code & $\begin{array}{c}\text { Reducing Sugar } \\
(\mathbf{m g} / \mathbf{m l})\end{array}$ & $\begin{array}{c}\text { Enzyme Activity } \\
(\mathbf{U} / \mathbf{m l})\end{array}$ & $\begin{array}{c}\text { Protein Content } \\
\text { (mg) }\end{array}$ & $\begin{array}{c}\text { Specific Activity } \\
\text { (nkat/mg protein) }\end{array}$ \\
\hline A1 & 5,525 & 1.42 & 0.195 & 2.30 \\
A4 & 7,880 & 2.07 & 0.102 & 6.14 \\
A6 & 3,867 & 0.96 & 0.213 & 1.43 \\
\hline
\end{tabular}

The amylase enzyme's specific activity was obtained from the comparison of the amylase enzyme activity units and protein content based on the regression equation formed from the BSA standard curve. Enzyme specific activity indicates the degree of purity of an enzyme. Table 2 shows that isolate A4 obtained a protein content of $0.102 \mathrm{mg}$ with a specific amylase enzyme activity of $6.14 \mathrm{nkat} / \mathrm{mg}$ protein.
According to Silaban and Simamora (Silaban \& Simamora, 2018), the specific activity of an enzyme (nkat/mg) is directly proportional to the activity of crude enzyme extract $(\mathrm{U} / \mathrm{ml})$ and inversely proportional to the level of enzyme protein (mg). The lower the protein content of an enzyme or the higher the specific activity, the higher the enzyme's purity level will be.

Table 3. The Characters of Amylolytic Bacteria Isolates A1, A4, and A6

\begin{tabular}{lccc}
\hline \multirow{2}{*}{ Characters } & \multicolumn{3}{c}{ Isolates } \\
\cline { 2 - 4 } & A1 & A4 & A6 \\
\hline Gram stain & Positive & Positive & Negative \\
Endospore Staining & - & Present & - \\
Cell Shape & Short stem & Stem & Short stem \\
\hline Catalase & + & + & + \\
Indole & - & - & + \\
MR / VP & $-/$ & $-/+$ & $-/+$ \\
\hline Citric Acid Production & - & + & + \\
Glucose Fermentation & + & + & - \\
Dextrose Fermentation & + & + & - \\
Lactose Fermentation & + & + & - \\
Sucrose Fermentation & + & - & - \\
H2S production & - & - & - \\
NaCl 6.5\% & - & & - \\
\hline
\end{tabular}

Table 3 shows the characterization results of three isolates with the highest amylase enzyme activity. The results obtained from the Gram stain observations indicated that the A1 and A4 isolates were Gram-positive bacteria marked by the formation of a purple color on the bacterial cells and A6 isolates were Gram-negative bacteria marked by the formation of red color on the bacterial cells. The three isolates also had stems or short stem cell forms. Thairu (Thairu et al., 2014) state that
Gram staining was carried out to know bacterial cells' morphology and determine the Gram-positive or Gram-negative bacterial groups. Bacteria with a positive Gram group were then tested for endospores and produced A4 isolates capable of forming endospores. Endospore protects the bacteria from unfavorable environments.

Physiological tests were carried out to determine the physiological abilities of the amylolytic bacterial isolates. In the catalase 
test, the three isolates reacted positively to catalase indicated by air bubbles forming on the slide after being dripped with $3 \% \mathrm{H}_{2} \mathrm{O}_{2}$ solution. The results indicated that the bacteria were aerobic and had the enzyme catalase. Babiker (Babiker et al., 2017) states that catalase is an enzyme that can catalyze the breakdown of hydrogen peroxide (H2O2) into water and 02 . Hydrogen peroxide is toxic to cells because it can inactivate enzymes in cells. This test is important to do to determine the nature of bacteria's need for oxygen.

The indole test results were negative for isolates A1 and A4 and positive for isolates A6. The positive result is indicated by the formation of a red ring on the media. In contrast, the negative result is indicated by the formation of a yellow ring on the media. According to Darkoh (Darkoh et al., 2015), the indole test is performed to identify isolates in producing indole compounds due to the breakdown of tryptophan amino acids by the tryptophanase enzyme. The indole test's presence can be detected by adding a covax reagent containing amyl alcohol and will react to form indole from the breakdown of tryptophan amino acids, causing the formation of a red layer or ring on the surface of the media.

The MR test was used to determine the ability of bacteria to oxidize glucose by producing the final product in acid or mixed acid fermentation. If the methyl red indicator is added to the culture, it will produce a red color, which indicates that the bacteria can perform acid fermentation (Vashist et al., 2013). In this study, the MR test showed negative results for all three isolates indicated by the absence of a change in the media's color (still yellow) after being given the methyl red reagent. This result indicated that the bacteria could not completely oxidize glucose to acid.

The VP test was used to determine the ability of bacteria to ferment 2,3-butanediol. In this test, $40 \% \mathrm{KOH}$ and 5\% $\alpha$-naphthol were added. The $\mathrm{KOH}$ solution will oxidize acetoin to diacetyl, which will then be catalyzed by $\alpha$-naphthol so that the results will react with the guanidine group in peptone to form a red color (Vashist et al., 2013). Isolates A1 showed a negative result indicated by no color change on the media (still yellow). In contrast, isolates A4 and A6 showed positive results with a change in the media's color to red.

The citrate test aimed to determine the ability of bacteria to use citrate as the only carbon source. The components used in this test were the Simmon's citrate medium containing sodium citrate as a carbon source, ammonium phosphate as a nitrogen source, and a bromthymol blue $\mathrm{pH}$ indicator. Bacteria can use citrate if it grows in the medium and breaks down ammonium phosphate into ammonia. This causes an increase in $\mathrm{pH}$ and causes a change in the medium's color from green to blue (Talaiekhozani et al., 2015). The results showed that A1 isolates could not use citrate as a carbon source, and A4 and A6 isolates could use citrate as a carbon source.

Various sources such as glucose, dextrose, lactose, and sucrose were used in the sugar fermentation test. The results showed that isolates A1 and A4 were positive on the test, and isolate A6 was only positive for the lactose source but negative for glucose, dextrose, and sucrose. A positive result is indicated by a change in the media's color to yellow, indicating that the isolate can ferment the sugar source into organic acids with medium $\mathrm{pH}$ into acidic (Vashist et al., 2013).

The H2S test showed negative results for the three isolates indicated by no change in the media's color (red). This result indicated that the bacteria could not break down sulfur-containing amino acids. According to Talaiekhozani (Talaiekhozani et al., 2015), H2S formation will produce a blackish-purple color due to the deposition of ferosulfide $\mathrm{H} 2 \mathrm{~S} \mathrm{FeSO} 4$ reactions. The $6.5 \% \mathrm{NaCl}$ test also showed negative results 
for the three isolates indicated by the media's absence of turbidity. The results indicating that the bacteria could not live at high salt levels.

Based on the characterization results in Table 3, it can be concluded that isolates A1, A4, and A6 were assumed as bacteria belonging to the genus Corynebacterium, Bacillus, and Klebsiella. The genus prediction was based on Bergey's Manual of Determinative Bacteriology. The results of this study are relevant with Silaban and Simamora's statement (Silaban \& Simamora, 2018) that the genera of amylolytic bacteria quite widely known are Bacillus, Lactobacillus, Clostridium, Micrococcus, and Actinomycetes Nangin and Sutrisno (Nangin \& Sutrisno, 2014) states that several types of amylase-producing bacteria are from the genus Bacillus, Geobacillus, and Klebsiella.

\section{CONCLUSIONS AND SUGGESTIONS}

Eight isolates of amylase-producing bacteria were successfully obtained from the soil samples. Three isolates were selected in quantitative amylase activity testing with the highest specific activity values, namely isolate $\mathrm{A} 4$ at $6.14 \mathrm{nkat} / \mathrm{mg}$ protein, isolate $\mathrm{A} 1$ at $2.30 \mathrm{nkat} / \mathrm{mg}$ protein, and isolate A6 at $1.43 \mathrm{nkat} / \mathrm{mg}$ protein. Isolates $\mathrm{A} 4, \mathrm{~A} 1$, and A6 belonged to the genus Bacillus, Corynebacterium, and Klebsiella. Based on the analysis, further researchers suggested that further researchers examine the amylase from other origins that are easier and uncommon. It is also suggested to research the isolation and activity of other enzymes.

\section{REFERENCES}

Abel-Nabey, H. M., \& Farag, A. M. (2016). Production, optimization and characterization of extracellular amylase from halophilic Bacillus lichineformis AH214. African Journal of Biotechnology, 15(17), 670-683.

Anggraini, A., \& Yunianta, Y. (2014). Pengaruh Suhu Dan Lama Hidrolisis Enzim Papain Terhadap Sifat Kimia, Fisik Dan Organoleptik Sari Edamame [In Press Juli 2015]. Jurnal Pangan Dan Agroindustri, 3(3).

Ardiansyah, A., Nurlansi, N., \& Musta, R. (2018). Waktu Optimum Hidrolisis Pati Limbah Hasil Olahan Ubi Kayu (Manihot esculenta Crantz var. Lahumbu) Menjadi Gula Cair Menggunakan Enzim $\alpha$-Amilase Dan Glukoamilase. Indonesian Journal of Chemical Research, 5(2), 86-95.

Arifin, Z. (2008). Beberapa unsur mineral esensial mikro dalam sistem biologi dan metode analisisnya. Jurnal Litbang Pertanian, 27(3), 99-105.

Babiker, B. M., Ahmed, M. A. E., \& Ibrahim, H. M. (2017). Isolation \& Identification of Catalase Producing Bacillus spp: A Comparative Study. Int J Adv Res, 4, 1206-1211.

Burhanudin, B., Yusnaini, Y., Hakiki, A., \& Maryati, S. (2020). Pelatihan Perhitungan Biaya Produk Utama dan Sampingan pada Badan Usaha Milik Desa di Desa Kerinjing, Kabupaten Ogan Ilir. Sricommerce: Journal of Sriwijaya Community Services, 1(2), 79-84.

Darkoh, C., Chappell, C., Gonzales, C., \& Okhuysen, P. (2015). A rapid and specific method for the detection of indole in complex biological samples. Applied and Environmental Microbiology, 81(23), 8093-8097.

Febriani, H., \& Rahmadina, R. (2017). Buku Biologi Sel Unit Terkecil Penyusun Tubuh Makhluk Hidup. 
Fifendy, M., Irdawati, I., \& Yenti, N. (2015). Penapisan bakteri termofilik penghasil enzim amilase dari sumber air panas sapan sungai aro Kabupaten Solok Selatan. Eksakta Berkala Ilmiah Bidang MIPA, 1, 7381.

Haryati, S., \& Munandar, A. (2016). Diversity Identification of Home Industry of Shrimp Paste Product in Banten Province. Jurnal Perikanan Dan Kelautan, 1(1).

Kalesaran, R. C., Mandagi, R. J., \& Waney, E. Y. (2013). Analisa Faktor-Faktor yang Mempengaruhi Keputusan Konsumen dalam Pemilihan Lokasi Perumahan di Kota Manado. Jurnal Ilmiah Media Engineering, 3(3).

Kartawijaya, I. (2014). Prosiding Seminar Nasional. Prosiding Seminar Nasional Biodiversitas Dan Ekologi Tropika Indonesia (BioETI) Universitas Andalas, 1.

Melliawati, R., \& Nuryati, N. (2019). Production of Complex Amylase Enzymes from Aspergillus Awamori KT-11. Its Application to Hydrolyze Cassava and Taro Starch. Bioscience, 3(2), 95-105.

Nangin, D., \& Sutrisno, A. (2014). Enzim Amilase Pemecah Pati Mentah Dari Mikroba: Kajian Pustaka [In Press Juli 2015]. Jurnal Pangan Dan Agroindustri, 3(3).

Ningsih, D. R., Asnani, A., \& Fatoni, A. (2010). Pembuatan Dekstrin dari Pati Ubi Kayu Menggunakan Enzim Amilase dari Azospirillum sp. JG3 dan Karakterisasinya. Molekul, 5(1), 1521.
Oktavia, Y., Lestari, S. D., Lestari, S., \& Jannah, M. (2018). Optimasi Waktu Inkubasi Produksi Protease Dan Amilase Isolat Bakteri Asal Terasi Ikan Teri Stolephorus SP. Jurnal Ilmu Dan Teknologi Kelautan Tropis, 10(3), 719-725.

Osvaldo, Z. S., Putra, P., \& Faizal, M. (2012). Pengaruh konsentrasi asam dan waktu pada proses hidrolisis dan fermentasi pembuatan bioetanol dari alang-alang. Jurnal Teknik Kimia, 18(2).

Pratiwi, R. S., Susanto, T. E., \& Sutrisno, A. (2014). Enzim Kitinase Dan Aplikasi Di Bidang Industri: Kajian Pustaka [In Press Juli 2015]. Jurnal Pangan Dan Agroindustri, 3(3).

Purnawan, A., Capriyanti, Y., Kurniatin, P. A., \& Rahmani, N. (2016). Optimasi Produksi Enzim Amilase dari Bakteri Laut Jakarta (Arthrobacter arilaitensis). JURNAL BIOLOGI INDONESIA, 11(2).

Putra, D. P., Susilo, B., Nugroho, W. A., \& Ahmad, A. M. (2014). Analisis finansial pengolahan limbah biogas menjadi pellet ikan dan pupuk organik cair. Jurnal Keteknikan Pertanian Tropis Dan Biosistem, 2(1).

Rakhmawati, A., Yulianti, E., Rohaeti, E., UNY, J. P. B. F., \& UNY, J. P. K. F. (2012). Seleksi Bakteri Termofilik Pasca Erupsi Merapi Sebagai Penghasil Enzim Amilase dan Protease. Tidak Diterbitkan, Universitas Negeri Yogyakarta.

Remijawa, E. S., Rupidara, A. D., Ngginak, J., \& Radjasa, O. K. (2020). Isolasi Dan Seleksi Bakteri Penghasil Enzim Ekstraseluler Pada Tanah Mangrove Di Pantai Noelbaki. Jurnal Enggano Vol, 5(2), 164-180. 


\section{Biosfer, 10 (1) (2020) 181-189}

Monica Kharisma Swandi

Rokhati, N., Pramudono, B., Istirokhatun, T., Sulchan, M., Kresnianingrum, D. A., \& Dewi, L. K. (n.d.). Hidrolisis Enzimatik Kitosan Dengan Kombinasi Enzim Endo-Glucanase Dan Cellobiohydrolase. Reaktor, 15(4), 261-267.

Rusli, M. A. (2016). Analisis penilaian biaya pengelolaan limbah produksi untuk meningkatkan laba perusahaan. Jurnal Penelitian Teori \& Terapan Akuntansi (PETA), 1(1), 83-103.

Silaban, S., \& Simamora, P. (2018). Isolasi dan karakterisasi bakteri penghasil amilase dari sampel air tawar Danau Toba. EduChemia (Jurnal Kimia Dan Pendidikan), 3(2), 222-231.

Singh, V., Sharma, R., \& Sharma, P. (2015). Isolation, screening and optimization of amylase producing Bacillus sp. From soil. Asian Pacific Journal of Health Sciences, 2(3), 94-103.

Siregar, N. S. (2014). Karbohidrat. Jurnal Ilmu Keolahragaan, 13(02), 38-44.

Sukandar, U., Syamsuriputra, A. A., Lindawati, L., \& Trusmiyadi, Y. (2018). Sakarifikasi pati ubi kayu menggunakan amilase Aspergillus niger ITB CC L74. Jurnal Teknik Kimia Indonesia, 10(1), 1-8.

Supriyatna, A., Jauhari, A. A., \& Holydaziah, D. (2015). Aktivitas enzim amilase, lipase, dan protease dari larva Hermetia illucens yang diberi pakan jerami padi. JURNAL ISTEK, 9(2).

Susilawati, I. O., Batubara, U. M., \& Riany, H. (2015). Analisis Aktivitas Enzim Amilase Yang Berasal Dari Bakteri Tanah Di Kawasan Universitas Jambi. SEMIRATA 2015, 4(1).
Talaiekhozani, A., Alaee, S., \& Ponraj, M. (2015). Guidelines for quick application of biochemical tests to identify unknown bacteria. $A O B R$, 2(2), 65-82.

Thairu, Y., Nasir, I. A., \& Usman, Y. (2014). Laboratory perspective of gram staining and its significance in investigations of infectious diseases. Sub-Saharan African Journal of Medicine, 1(4), 168.

Vaidya, S., Srivastava, P. K., Rathore, P., \& Pandey, A. K. (2015). Amylases: A prospective enzyme in the field of biotechnology. J Appl Biosci, 41(1), 118.

Vashist, H., Sharma, D., \& Gupta, A. (2013). A review on commonly used biochemical test for bacteria. Innovare Journal of Life Science, 1(1), 1-7.

Vishnu, T. S., Soniyamby, A. R., Praveesh, B. V., \& Hema, T. A. (2014). Production and optimization of extracellular amylase from soil receiving kitchen waste isolate Bacillus sp. VS 04. World Appl. Sci. J, 29(7), 961-967.

Wardani, K. K., Prasetyawan, S., \& Mahdi, C. (2014). Karakterisasi Enzim Organofosfat Hidrolase (Oph) Dari Pseudomonas Putida Pada Substrat Klorpirifos Dan Profenofos. Jurnal Ilmu Kimia Universitas Brawijaya, 2(1), 365-371. 